\title{
PEMBELAJARAN KIMIA MENGGUNAKAN MODEL THINK PAIR SHARE(TPS) DAN NUMBER HEAD TOGETHER (NHT) DILENGKAPI HANDOUT DITINJAU DARI KEMAMPUAN AWAL DAN KEMAMPUAN MATEMATIK
}

\author{
Aisyah $^{1}$, M. Masykuri ${ }^{2}$, Sulistyo Saputro ${ }^{3}$ \\ ${ }^{1}$ Program Studi Pendidikan Sains Program Pascasarjana \\ Universitas Sebelas Maret Surakarta, 57126, Indonesia \\ aisyahusman92@yahoo.com \\ ${ }^{2}$ Program Studi Pendidikan Sains Program Pascasarjana \\ Universitas Sebelas Maret, 57126, Indonesia \\ mmasykuri@yahoo.com \\ ${ }^{3}$ Program Studi Pendidikan Sains Program Pascasarjana \\ Universitas Sebelas Maret, 57126, Indonesia \\ sulistyo68@yahoo.com
}

\begin{abstract}
ABSTRAK
Tujuan penelitian ini adalah untuk mengetahui pengaruh penggunaan model Think Pair Share (TPS) dan Number Head Together (NHT), kemampuan awal, kemampuan matematik, dan interaksi variabelnya terhadap prestasi belajar. Penelitian ini menggunakan model eksperimen semu dan dilaksanakan dari bulan Desember 2012 - Juni 2013. Populasi penelitian ini adalah semua siswa kelas XI IPA SMA N 1 Sragen Tahun Pelajaran 2012/2013. Sampel diperoleh dengan teknik cluster random sampling yang terdiri dari dua kelas, XI IPA 6 dan XI IPA 7. Kelas XI IPA 6 diberi pembelajaran dengan model NHT dan kelas XI IPA 7 diberi pembelajaran dengan model TPS. Data dikumpulkan dengan model tes untuk prestasi belajar kognitif, kemampuan awal, dan kemampuan matematik, angket untuk prestasi afektif, dan lembar observasi untuk psikomotor siswa. Hipotesis diuji menggunakan Anava (Analisis Variansi) dan Kruskal-Wallis one way analysis of variance. Dari hasil analisis data disimpulkan: 1) terdapat pengaruh penggunaan model TPS dan NHT terhadap prestasi belajar kognitif siswa, tetapi tidak terdapat pengaruhnya terhadap prestasi afektif dan psikomotor; 2) terdapat pengaruh kemampuan awal terhadap prestasi belajar kognitif dan psikomotor siswa, tetapi tidak terdapat pengaruhnya terhadap prestasi afektif; 3) terdapat pengaruh kemampuan matematik terhadap prestasi kognitif dan psikomotor siswa, tetapi tidak terdapat pengaruhnya terhadap prestasi afektif; 4) terdapat interaksi antara model pembelajaran TPS dan NHT dengan kemampuan awal terhadap prestasi belajar kognitif siswa, tetapi tidak terdapat interaksinya terhadap prestasi afektif dan psikomotor; 5) terdapat interaksi antara model pembelajaran TPS dan NHT dengan kemampuan matematik terhadap prestasi kognitif siswa, tetapi tidak terdapat interaksinya terhadap prestasi afektif dan psikomotor; 6) terdapat interaksi antara kemampuan awal dan kemampuan matematik terhadap prestasi kognitif dan afektif siswa, tetapi tidak terdapat interaksinya terhadap prestasi psikomotor; 7) terdapat interaksi antara model pembelajaran TPS dan NHT, kemampuan awal, dan kemampuan matematik terhadap prestasi kognitif siswa, tetapi tidak terdapat interaksinya terhadap prestasi afektif dan psikomotor.
\end{abstract}

Kata kunci: Think Pair Share (TPS), Number Head Together (NHT), kemampuan awal, kemampuan matematik, kelarutan dan Ksp.

\section{Pendahuluan}

Hasil observasi di SMAN 1 Sragen menunjukkan guru belum sepenuhnya menerapkan model pembelajaran yang inovatif serta guru kurang memperhatikan faktor internal siswa dalam menentukan model pembelajaran yang digunakan. Alasan guru masih menggunakan model ceramah karena praktis dan tidak banyak menyita waktu, tetapi siswa menjadi kurang aktif dan kurang berminat dalam pelajaran kimia. Terdapat gap antara siswa yang pandai dan kurang pandai. Siswa pandai mudah menerima materi belajar, memiliki catatan yang lengkap dan mendapatkan hasil belajar jauh lebih tinggi. Sedangkan siswa yang kurang pandai sulit 
menerima materi belajar, tidak memiliki catatan yang lengkap dan mendapatkan hasil belajar yang jauh lebih rendah. Adanya gap antara siswa pandai dan kurang pandai membuat sifat individualistik tinggi sedangkan kerjasama kelompok dan interaksi sosial diantara siswa kurang.

Model pembelajaran inovatif yang sesuai dengan kurikulum diperlukan untuk memudahkan siswa memahami materi kimia. Salah satu model pembelajaran yang sesuai dengan kurikulum KTSP yaitu model cooperative learning (pembelajaran kooperatif). Cooperative learning merupakan pendekatan pembelajaran melalui penggunaan kelompok kecil siswa untuk bekerja sama dalam memaksimalkan kondisi belajar dalam mencapai tujuan belajar (Holubec cit. Nurhadi dkk, 2004). Usaha kerja sama masing-masing anggota kelompok mengakibatkan manfaat timbal balik sedemikian rupa sehingga semua anggota kelompok memperoleh prestasi, kegagalan dan keberhasilan ditanggung bersama. Partisipasi siswa dalam pembelajaran dan penggunaan model yang menyenangkan akan membantu memahami, dan menguasai kompetensi pembelajaran.

Tipe cooperative learning yang akan digunakan dalam penelitian ini yaitu Think Pair Share (TPS). Menurut Azlina (2010) tahapan model TPS yaitu think (berfikir individu), setiap siswa memikirkan persoalan yang diberikan guru secara mandiri membentuk ide-ide dari pemikiran mereka tentang persoalan tersebut. Kemudian pair (berpasangan), siswa berpasangan dengan yang siswa lain untuk mendiskusikan apa yang telah menjadi ide-ide mereka dari tahapan think sehingga terjadi interaksi dan berbagi jawaban tentang permasalahan yang telah diberikan kemudian mengambil keputusan bersama. Selanjutnya share (berbagi), siswa berbagi dengan teman sekelas dengan mempresentasikan atau melaporkan hasil diskusi, dengan tujuan untuk mengetahui apakah ada persamaan atau perbedaan jawaban dengan pasangan yang lain.

Tipe cooperative learning yang lain yaitu Number Head Together (NHT). Menurut Kagan (2009) tahapan dalam model Number Head Together (NHT) yaitu: pembentukan kelompok yang terdiri dari 4 anggota dan diberi nomor 1 sampai 4. Kemudian guru memberikan permasalahan dan masing-masing kelompok mengerjakannya. Selanjutnya siswa dalam setiap kelompok berdiskusi dan memastikan semua siswa dalam kelompok memahami dan mengetahui serta dapat memberikan jawaban. Tahap yang terakhir guru memanggil nomor secara acak dengan nomor yang dipanggil menjawab/mempresentasikan mewakili dirinya sendiri dan kelompoknya. TPS merupakan kelompok kooperatif yang lebih kecil hanya terdiri dari dua siswa sedangkan NHT adalah kelompok kooperatif yang lebih besar karena terdiri dari 4 anggota siswa. Kedua model TPS dan NHT menuntut siswa bekerja sama untuk memecahkan masalah dalam kelompok. Menurut Johnson and Johnson cit. Morgan (2010) mengatakan ada lima komponen dalam pembelajaran kooperatif yaitu: ketergantungan positif, interaksi tatap muka, akuntabilitas individual, keterampilan untuk menjalin hubungan antarpribadi atau keterampilan sosial dan proses.

Faktor internal yang berasal dari diri siswa dapat mempengaruhi prestasi belajar. Faktor internal yang diperhatikan dalam pembelajaran diantaranya adalah kemampuan awal dan kemampuan matematik. Menurut Biemans dan Simon's cit. Strangman and Hall (2004) kemampuan awal adalah semua pengetahuan siswa yang telah dimiliki dan ketika masuk dalam lingkungan belajar berpotensi berhubungan untuk memahami pengetahuan baru yang akan disampaikan. Komponen kemampuan awal yang digunakan yaitu pengetahuan yang telah diperoleh ditingkat sebelumnya berupa persamaan reaksi, konsep mol, larutan elektrolitnon elektrolit, kesetimbangan kimia dan faktorfaktor yang mempengaruhinya serta larutan asam, basa, garam dan perhitungannya.

Kemampuan matematik menurut Kovas (2007) yaitu kemampuan dalam pengoperasian angka (operasi penjumlahan dan pengurangan, operasi perkalian, pembagian dan perbandingan) dan juga proses aljabar yang digunakan dalam menyelesaikan permasalahan hitungan. Komponen yang digunakan yaitu kemampuan dalam melakukan operasi penjumlahan dan pengurangan, operasi perkalian dan pembagian, pengubahan bilangan, operasi logaritma, dan kesebandingan.

Materi kimia yang dipilih dalam penelitian ini yaitu kelarutan dan hasil kali kelarutan (contanta of solubility product, Ksp). Pemilihan materi ini sangat erat kaitannya dengan model pembelajaran yang digunakan serta faktor internal yang diperhatikan. Materi kelarutan dan Ksp cocok diajarkan dengan model TPS dan NHT karena banyak permasalahan yang perlu 
dipecahkan oleh siswa dan untuk mempermudah penyelesaian masalah maka perlu dilengkapi dengan handout. Kemampuan awal dan kemampuan matematik merupakan kemampuan yang sangat diperlukan oleh siswa dalam menyelesaikan masalah. Harapannya dengan penerapan kedua model pembelajaran ini dan memperhatikan kemampuan awal serta kemampuan matematik akan mempunyai pengaruh terhadap prestasi belajar siswa baik itu prestasi kognitif, afektif, maupun psikomotor.

Bloom cit. Depdiknas (2003), menjelaskan bahwa ranah kognitif merupakan ranah yang berkaitan dengan kompetensi berpikir, memperoleh pengetahuan, pengenalan, pemahaman, konseptualisasi, penentuan, dan penalaran. Ranah afektif adalah ranah yang berkaitan dengan perasaan, emosi, sikap, dan derajat penerimaan atau penolakan terhadap suatu objek (Depdiknas 2008). Ranah psikomotor menurut Bloom cit. Depdiknas (2008) berhubungan dengan hasil belajar yang pencapaiannya melalui keterampilan manipulasi yang melibatkan otot dan kekuatan fisik.

Berdasarkan uraian di atas, ada beberapa tujuan penelitian ini yaitu untuk mengetahui adanya : 1) pengaruh pembelajaran kimia dengan menggunakan model pembelajaran Think Pair Share (TPS) dan Number Head Together (NHT) terhadap prestasi belajar siswa; 2) pengaruh kemampuan awal terhadap prestasi belajar siswa; 3) pengaruh kemampuan matematik terhadap prestasi belajar siswa; 4) interaksi antara model pembelajaran Think Pair Share (TPS) dan Number Head Together (NHT) dengan kemampuan awal siswa terhadap prestasi belajar siswa; 5) interaksi antara model pembelajaran Think Pair Share (TPS) dan Number Head Together (NHT) dengan kemampuan matematik terhadap prestasi belajar siswa; 6) interaksi antara kemampuan awal dan kemampuan matematik terhadap prestasi belajar siswa; 7) interaksi antara model pembelajaran Think Pair Share (TPS) dan Number Head Together (NHT) kemampuan awal, dan kemampuan matematik terhadap prestasi belajar siswa.

\section{Model Penelitian}

Penelitian ini dilaksanakan di kelas XI IPA semester 2 SMA N 1 Sragen pada tahun pelajaran 2012/2013. Penelitian ini dilaksanakan pada bulan April 2013 - Juni 2013. Model yang digunakan adalah eksperimen semu dengan dua kelompok eksperimen tanpa kelas kontrol. Kelompok eksperimen pertama diberi perlakuan dengan model pembelajaran $N H T$, sedangkan kelompok kedua diberi perlakuan dengan model pembelajaran TPS. Kedua kelompok tersebut diberikan tes kemampuan awal dan tes kemampuan matematik sebelum melakukan pembelajaran. Kemampuan awal dibagi menjadi dua kategori, yaitu kemampuan awal tinggi dan rendah. Demikian pula dengan kemampuan matematik. Pengkategorian ini didasarkan pada nilai acuan normal atau nilai rata-rata seluruh kelas penelitian karena instrumen yang digunakan dalam pengambilan data bukan instrumen yang sudah baku. Penilaian psikomotor dilakukan pada saat siswa melakukan praktikum. Selanjutnya setelah proses pembelajaran selesai, dilakukan penilaian prestasi belajar untuk ranah kognitif dan afektif.

Populasi dalam penelitian ini adalah siswa kelas XI IPA SMA N 1 Sragen Tahun Pelajaran 2012/2013. Sebelum melakukan pengambilan sampel, terlebih dahulu dilakukan uji beda rerata populasi dengan uji anava satu jalan. Teknik pengambilan sampel yang digunakan yaitu cluster random sampling, yaitu teknik memilih sampel dari kelompok-kelompok atau unit-unit kecil dari populasi secara acak dengan cara undian. Undian tersebut dilaksanakan satu tahap dengan dua kali pengambilan. Hasilnya yaitu kelas XI IPA 6 diberi perlakuan menggunakan model NHT dan XI IPA 7 diberi perlakuan menggunakan model TPS.

Variabel bebas yang digunakan yaitu model pembelajaran NHT dan TPS. Variabel moderator terdiri dari kemampuan awal dan kemampuan matematik. Adapun variabel terikat terdiri dari prestasi belajar ranah kognitif, afektif, dan psikomotor.

Sumber data dalam penelitian ini disusun relevan dengan variabel penelitian dan model pengumpulan data. Instrumen yang digunakan untuk pengambilan data prestasi belajar ranah kognitif, kemampuan berpikir kritis, dan kemampuan matematik berupa tes. Sedangkan untuk prestasi ranah afektif diukur menggunakan angket, prestasi ranah psikomotor diukur menggunakan lembar observasi yang disesuaikan dengan jenis praktikum yang dilakukan.

Tes digunakan untuk mengukur kemampuan awal, kemampuan matematik, dan prestasi belajar kognitif adalah tes objektif berbentuk pilihan ganda. Jenis angket yang digunakan untuk pengukuran prestasi afektif adalah angket langsung dan tertutup, yaitu daftar pertanyaan diberikan langsung kepada responden dan alternatif jawaban sudah disediakan dalam 
angket. Penyusunan angket menggunakan skala Likert dengan skala 1 sampai 4.

Instrumen yang digunakan meliputi instrumen pelaksanaan penelitian terdiri dari silabus dan RPP dan instrumen pengambilan data terdiri dari tes kemampuan berpikir kritis, kemampuan matematis, dan prestasi belajar. Sebelum melakukan uji coba istrumen, semua instrumen yang digunakan harus divalidasi isi oleh pakar. Setelah itu dilakukan uji coba instrumen untuk mengukur validitas, reliabilitas, daya pembeda, dan tingkat kesukaran soal.

\section{Hasil Penelitian dan Pembahasan}

Data yang diperoleh berupa skor kemampuan awal, skor kemampuan matematik, dan skor prestasi belajar siswa pada pokok materi kelarutan dan hasil kali kelarutan (constanta of solubility product, Ksp) yang meliputi prestasi belajar kognitif, afektif, dan psikomotor. Deskripsi data dapat dilihat pada Tabel 1.

Tabel 1. Data prestasi belajar siswa

\begin{tabular}{ccccccc}
\hline $\begin{array}{l}\text { Model } \\
\begin{array}{l}\text { Pembela } \\
\text { jaran }\end{array}\end{array}$ & $\begin{array}{l}\text { Kemam } \\
\text { puan } \\
\text { Awal }\end{array}$ & $\begin{array}{c}\text { Kemampuan } \\
\text { Matematik }\end{array}$ & $\begin{array}{c}\text { Jumlah } \\
\text { siswa }\end{array}$ & $\begin{array}{l}\text { Kogni } \\
\text { tif }\end{array}$ & Afektif & $\begin{array}{l}\text { Psiko } \\
\text { motor }\end{array}$ \\
\hline NHT & Tinggi & Tinggi & 10 & 80,58 & 91,33 & 83,10 \\
& & Rendah & 7 & 77,70 & 82,53 & 81,14 \\
& Rendah & Tinggi & 6 & 75,70 & 84,61 & 82,17 \\
& & Rendah & 9 & 63,90 & 88,32 & 80,56 \\
\hline TPS & Tinggi & Tinggi & 8 & 84,00 & 85,67 & 82,63 \\
& & Rendah & 8 & 77,08 & 79,17 & 81,88 \\
& \multirow{2}{*}{ Rendah } & Tinggi & 9 & 79,86 & 84,02 & 82,11 \\
& & Rendah & 7 & 70,15 & 89,45 & 81,57 \\
\hline
\end{tabular}

Tabel 1 menyajikan data prestasi kognitif tertinggi diperoleh oleh kelompok TPS dengan kemampuan awal tinggi dan kemampuan matematik tinggi, sedangkan prestasi kognitif terendah diperoleh oleh kelompok NHT dengan kemampuan awal rendah dan kemampuan matematik rendah. Prestasi afektif tertinggi diperoleh oleh kelompok NHT dengan kemampuan awal tinggi dan kemampuan matematik tinggi, sedangkan prestasi afektif terendah diperoleh oleh kelompok TPS dengan kemampuan awal tinggi dan kemampuan matematik rendah. Prestasi psikomotor tertinggi diperoleh oleh kelompok NHT dengan kemampuan awal tinggi dan kemampuan matematik tinggi, sedangkan prestasi psikomotor terendah diperoleh oleh kelompok NHT dengan kemampuan awal rendah dan kemampuan matematik rendah.

Analisis data yang digunakan dalam penelitian ini adalah untuk prestasi kognitif menggunakan Kruskal Wallis Test. Sedangkan analisis data prestasi afektif dan psikomotor menggunakan Anava (analisys of varians) $2 \times 2 \times 2$.

Rangkuman data hasil pengujian hipotesis disajikan dalam Tabel 2.

Tabel 2. Uji Hipotesis Penelitian Prestasi Belajar

\begin{tabular}{clccc}
\hline \multirow{2}{*}{$\begin{array}{l}\text { Hipo } \\
\text { Tesis }\end{array}$} & Grouping Variable & \multicolumn{3}{c}{ Nilai Signifikansi } \\
\cline { 3 - 5 } & Kognitif & Afektif & $\begin{array}{l}\text { Psiko } \\
\text { motor }\end{array}$ \\
\hline 1 & Model & 0,010 & 0,970 & 0,490 \\
\hline 2 & Kemampuan awal & 0,000 & 0,280 & 0,010 \\
\hline 3 & Kemampuan matematik & 0,000 & 0,770 & 0,030 \\
\hline 4 & Model * Kemampuan awal & 0,000 & 0,610 & 0,140 \\
\hline 5 & $\begin{array}{l}\text { Model * Kemampuan } \\
\text { matematik }\end{array}$ & 0,000 & 0,470 & 0,900 \\
\hline 6 & $\begin{array}{l}\text { Kemampuan awal * } \\
\text { Kemampuan matematik }\end{array}$ & 0,000 & 0,000 & 0,420 \\
\hline 7 & $\begin{array}{l}\text { Model * Kemampuan awal } \\
\text { * Kemampuan matematik }\end{array}$ & 0,000 & 0,190 & 0,580 \\
\hline
\end{tabular}

Berdasarkan Tabel 2 dapat dibahas mengenai hasil pengujian hipotesis pada ranah kognitif, afektif, dan psikomotor sebagai berikut:

1) Pengaruh model pembelajaran NHT dan TPS terhadap prestasi belajar

Pembelajaran kooperatif (cooperative learning) berakar pada teori - teori ketergantungan sosial, pengembangan kognitif dan pembelajaran tingkah laku (Morgan, 2010). Sejumlah besar penelitian yang telah dilakukan menunjukkan bahwa pembelajaran kooperatif menghasilkan prestasi yang lebih besar, mempunyai hubungan positif dan memberikan dampak psikologis yang lebih baik dibandingkan dengan pembelajaran kompetitif ataupun individualisme (Johnson \& Johnson cit. Morgan 2010). Salah satunya adalah penelitian yang dilakukan Peklaj (2000) yang menyimpulkan bahwa pembelajaran kooperatif secara umum berpengaruh positif terhadap pencapaian aspek kognitif, afektif, metakognitif dan proses sosial. Hal ini sesuai dengan pernyatan Slavin (2008) bahwa "Pembelajaran kooperatif membantu guru untuk menciptakan lingkungan belajar yang berpusat pada siswa yang dapat meningkatkan prestasi akademik, afektif dan perkembangan individu dalam bersosialisasi". Demikian pula penelitian yang dilakukan Morgan (2010) menunjukkan perubahan yang signifikan pada pretes dan postes, interaksi yang menyenangkan dalam kelompoknya dan meningkatkan performa semua siswa.

Model pembelajaran NHT dan TPS memiliki sintak yang hampir sama. Tahap awal siswa diberikan permasalahan yang menyangkut kelarutan dan Ksp, kemudian siswa mencari solusi dari permasalahan, dan terakhir mengkomunikasikan hasil pemecahannya. Perbedaan model ini terletak pada pembentukan 
kelompok, pada NHT kelompok diskusi terdiri dari 4 siswa sedangkan pada TPS terdiri dari 2 siswa berpasangan. Selanjutnya dalam NHT, siswa dalam kelompok berdiskusi langsung megenai permasalahan yang diberikan dan masing-masing siswa harus mengetahui jawaban dari permasalahan tersebut sampai ketika nomornya dipanggil secara acak oleh guru untuk kemudian mempresentasikannya ke depan kelas. Sedangkan pada TPS sebelum siswa berdikusi bersama pasangannya, terlebih dahulu masingmasing individu diberi kesempatan untuk berfikir sesuai dengan potensinya terhadap suatu permasalahan yang diberikan. Setelah itu baru siswa bergabung dengan pasangannya untuk berdiskusi menyamakan pendapat atau pandangaannya terhadap penyelesaian permasalahan tersebut selanjutnya pasangan tersebut mempresentasikan ke depan kelas.

Salah satu kelebihan kerja kelompok kooperatif adalah pada bantuan yang saling diberikan oleh para murid serta dapat mengembangkan sikap sosial siswa. Dalam kelompok NHT memiliki lebih banyak anggota diharapkan ide-ide dalam penyelesaian masalah lebih banyak diperoleh dari masing-masing anggota. Akan tetapi dengan banyak anggota juga mempunyai kelemahan seperti yang diungkapkan oleh Muijs et al. (2008) yaitu tidak mengembangkan belajar mandiri dan dapat menimbulkan ketergantungan pada anggota dominan di kelompok. Seperti halnya pada penelitian ini, ketika siswa berdiskusi mengenai kelarutan dan Ksp ada beberapa siswa yang terlihat pasif hanya menunggu jawaban dari anggota kelompoknya yang pintar. Sedangkan pada kelompok TPS hanya terdiri dari dua anggota lebih sedikit dibanding pada kelompok NHT. Menurut Anita (2003) model Think Pair Share (TPS) mempunyai kelebihan pada tingginya partisipasi anggota kelompok, cocok untuk penyelesaian yang sederhana lebih banyak kesempatan dalam konstribusi anggota kelompok dan interaksi menjadi lebih mudah. Masih menurut Anita (2003) model TPS juga mempunyai kelemahan yaitu lebih banyak kelompok yang melapor, lebih sedikit ide yang muncul dalam kelompok, jika ada perselisihan tidak ada penengah karena setiap kelompok hanya terdiri dari dua anggota.

Kaitannya dengan hasil pengujian hipotesis maka terdapat perbedaan signifikan model pembelajaran yang diterapkan dengan prestasi kognitif siswa. Nilai rata-rata kognitif pada model NHT dan TPS berturut-turut 81,26 dan
82,63 . Hal ini menunjukkan rerata prestasi belajar pada model TPS lebih unggul dari pada model NHT. Kenyataan pembelajaran dalam kelas pada model NHT yang merupakan kelompok dengan 4 siswa masih terlihat pada beberapa kelompok, keaktifan dari siswa yang pandai lebih dominan sementara siswa yang kurang pandai masih terlihat pasif kurang percaya diri, dan terdapat siswa yang pandai tetapi berkarakter pendiam sehingga dalam memecahkan masalah kurang terampil untuk berbagi dengan teman yang lain. Sedangkan pada model TPS terlihat antusias pasangan dalam berdiskusi dan pada saat diberi kesempatan untuk sharing di depan kelas terlihat pasanganpasangan yang berlomba untuk dapat tampil ke depan kelas. Model pembelajaran TPS menunjukkan siswa lebih banyak mengembangkan ide-idenya dan partisipasinya dalam pasangannya karena jumlah anggotanya lebih sedikit dibanding dengan dalam model NHT. Kenyataan model TPS lebih unggul dibandingkan NHT menunjukkan juga karakteristik siswa lebih suka pada kelompok kecil daripada kelompok besar.

Hasil analisis data afektif dan psikomotor disimpulkan tidak ada pengaruh yang signifikan pada model pembelajaran terhadap prestasi afektif dan psikomotor siswa. Tidak adanya pengaruh model pembelajaran terhadap prestasi afektif disebabkan karena perubahan perilaku afektif melalui proses yang membutuhkan waktu lebih lama tidak serta merta dibandingkan aspek kognitif dan dukungan dari lingkungan (Diknas 2008). Waktu yang relatif singkat dan tidak adanya dukungan lingkungan mengakibatkan kurang terlihatnya dampak model pembelajaran terhadap prestasi belajar afektif. Selanjutnya tidak terdapat pengaruh model pembelajaran terhadap prestasi psikomotor disebabkan dalam praktikum siswa bekerjasama dengan baik dalam kelompoknya.

2) Pengaruh kemampuan awal terhadap prestasi belajar

Kemampuan awal merupakan salah satu faktor internal yang mendukung pencapaian prestasi belajar termasuk prestasi kognitif, salah satu contohnya dalam materi kelarutan dan hasil kali kelarutan (constanta of solubility product, Ksp). Materi kelarutan dan Ksp merupakan materi kimia kelas XI IPA yang tidak terlepas dari konsep-konsep materi sebelumnya, sehingga materi kelarutan dan Ksp akan lebih mudah dipahami apabila siswa menguasai pengetahuan/kemampuan awal yang telah 
didapatkan sebelumnya. Kemampuan awal yang dibutuhkan terkait materi kelarutan dan Ksp yaitu konsep persamaan reaksi, sthoikiometri, larutan elektrolit-non elektrolit, kesetimbangan kimia, larutan asam, basa, garam.

Kaitannya dengan hasil pengujian hipotesis maka terdapat pengaruh kemampuan awal terhadap prestasi kognitif siswa. Siswa dengan kemampuan awal tinggi mempunyai nilai ratarata yang lebih tinggi dibandingkan dengan siswa yang berkemampuan awal rendah berturut-turut 81,27 dan 75,00. Hal ini sejalan dengan penelitian Dochy, Segers dan Buehl (1999) yang menunjukkan bahwa kemampuan awal meningkatkan performa siswa sampai $81 \%$ varian terhadap skor post test. Siswa dengan kemampuan awal tinggi akan mempermudah proses belajar karena kemampuan awal yang tinggi mempunyai keterhubungan tinggi secara materi yang mempermudah penguasaan materi baru sehingga secara langsung dapat meningkatkan prestasi belajar kognitif.

Hasil analisis afektif menunjukkan tidak ada pengaruh yang signifikan antara siswa yang berkemampuan awal tinggi dengan siswa yang berkemampuan awal rendah terhadap prestasi afektif. Tidak adanya pengaruh disebabkan karena perubahan perilaku afektif melalui proses yang membutuhkan waktu lebih lama tidak serta merta dibandingkan aspek kognitif dan dukungan dari lingkungan (Depdiknas, 2008). Selanjutnya hasil analisis prestasi psikomotor menunjukkan adanya pengaruh antara siswa yang berkemampuan awal tinggi dengan siswa yang berkemampuan awal rendah terhadap prestasi psikomotor. Hal ini disebabkan karena penguasaan kemampuan awal yang tinggi mempengaruhi kepercayaan diri seorang siswa untuk melakukan pemilihan suatu alat praktikum dan melakukan suatu pencampuran bahan-bahan dalam kegiatan praktikum dengan terampil.

3) Pengaruh kemampuan matematik terhadap prestasi belajar

Kemampuan matematik berkaitan dengan pengoperasian angka, proses pemahaman yang bukan angka, perhitungan sederhana menggunakan model kertas-pensil dan mengingat kembali fakta matematika dan istilahistilahnya (Kovas, 2007). Kemampuan matematik merupakan salah satu faktor internal yang mendukung keberhasilan kognitif siswa dalam melakukan ketepatan penghitungan matematika yang dibutuhkan dalam materi kelarutan dan Ksp. Perhitungan dalam materi kelarutan dan Ksp meliputi operasi hitung dasar seperti penjumlahan, pengurangan, perkalian dan pembagian, logaritma sederhana. Selain itu kemampuan matematik yang diperlukan adalah penggunaan notasi atau rumus yang sesuai. Dalam materi kelarutan dan Ksp indikator soal yang menguji kemampuan matematik sebanyak $63 \%$ misalnya dalam mencari nilai kelarutan suatu zat, nilai $\mathrm{Ksp}$, nilai konsentrasi, nilai $\mathrm{pH}$, serta nilai penentuan terjadinya pengendapan.

Kaitannya dengan hasil pengujian hipotesis maka terdapat pengaruh kemampuan matematik terhadap prestasi kognitif siswa. Siswa yang mempunyai kemampuan matematik tinggi mempunyai prestasi kognitif lebih tinggi dibandingkan dengan siswa yang berkemampuan matematik rendah. Hal ini dapat dilihat dari nilai rata-rata kognitif antara siswa berkemampuan matematik tinggi dengan siswa berkemampuan matematik rendah berturut-turut adalah 80,58 dan 68,76. Berdasarkan perkembangan kognitif Piaget, siswa SMA berada pada tingkat operasional formal. Dalam masa ini anak dapat menggunakan operasi kongkret yang dimiliki untuk membentuk operasi-operasi yang lebih kompleks.

Hasil uji prestasi afektif menunjukkan tidak ada pengaruh kemampuan matematik tinggi dan rendah terhadap prestasi afektif karena angket afektif siswa tidak berhubungan dengan soal perhitungan yang membutuhkan kemampuan matematik. Sedangkan hasil uji prestasi psikomotor menunjukkan adanya pengaruh kemampuan matematik tinggi dan rendah terhadap prestasi psikomotor. Hal ini disebabkan dalam melakukan praktikum dibutuhkan ketelitian dan ketepatan dalam hal pengambilan tindakan yang harus dilakukan dengan tepat dan hati-hati jika siswa tersebut mempunyai kemampuan perhitungan yang baik.

4) Interaksi penggunaan model pembelajaran

NHT dan TPS dengan kemampuan awal terhadap prestasi belajar.

Siswa dengan kemampuan awal tinggi jika diberi pembelajaran dengan model TPS mempunyai rerata prestasi yang lebih baik dibandingkan dengan jika diberi pembelajaran dengan model NHT berturut-turut 74,00 dan 72,67. Demikian pula pada siswa dengan kemampuan awal rendah mempunyai rerata prestasi yang lebih baik jika diberi pembelajaran dengan model TPS dibandingkan dengan jika diberi pembelajaran dengan model NHT berturut-turut 61,00 dan 57,33 . Sehingga dapat disimpulkan terdapat interaksi antara model pembelajaran TPS dan NHT dengan kemampuan 
awal siswa. Secara statistik model TPS lebih unggul dibandingkan dengan model NHT, faktor yang menyebabkan berdasarkan pembelajaran di kelas adalah siswa pada model TPS lebih kompak dan lebih leluasa melakukan diskusi dan bertukar ide tentang suatu permasalahan dan menyadari apabila mereka tidak dapat menyelesaikan permasalahan tersebut akan terlihat cukup jelas oleh pasangan-pasangan yang lain, sehingga siswa yang berkemampuan awal tinggi yang lebih menguasai materi dapat lebih leluasa untuk mengajarkan pada siswa yang kemampuan awalnya rendah. Sedangkan pada model NHT yang terdiri lebih banyak siswa terkadang hanya saling mengharapkan kepada siswa yang lebih pandai saja, terdapat kecenderungan adanya siswa yang lebih aktif mendominasi interaksi dalam kelompok dan semakin besar kecenderungan adanya siswa yang kurang aktif. Dengan kata lain karakteristik siswa lebih suka pada kelompok kecil dibandingkan kelompok besar. Selanjutnya karakteristik materi kelarutan dan Ksp merupakan materi yang dapat dikatakan mudah dipahami dan mudah penyelesaiannya, terlihat dari indikator soal pada tingkat pengetahuan (C1) sebesar 14,8\%, pemahaman (C2) sebesar 44,5\%, aplikasi (C3) sebesar $29,6 \%$ dan analisis (C4) sebesar $11,1 \%$. Hal ini juga sesuai dengan karakteristik model TPS yang cocok untuk penyelesaian masalah yang sederhana.

Hasil uji prestasi afektif dan psikomotor menunjukkan tidak ada interaksi antara penggunaan model pembelajaran NHT dan TPS dengan kemampuan awal tinggi dan rendah terhadap prestasi belajar afektif dan prestasi belajar psikomotor. Tidak adanya interaksi antara model pembelajaran dengan kemampuan awal tinggi dan rendah terhadap prestasi afektif disebabkan karena perubahan perilaku afektif melalui proses yang membutuhkan waktu lebih lama tidak serta merta dibandingkan aspek kognitif dan dukungan dari lingkungan (Diknas 2008). Selain itu pertanyaan-pertanyaan dalam angket untuk mengukur prestasi afektif tidak membutuhkan kemampuan awal akan tetapi lebih kepada sikap dan perilaku siswa secara umum terhadap pembelajaran kelarutan dan Ksp. Selanjutnya tidak terdapat interaksi antara model pembelajaran dengan kemampuan awal tinggi dan rendah terhadap prestasi psikomotor disebabkan lembar observasi untuk penilaian psikomotor melalui praktikum lebih ditekankan pada aspek keterampilan siswa misalnya dalam menggunakan alat dan melakukan pencampuran larutan yang tidak terlalu dipengaruhi oleh kemampuan awal siswa dan siswa dalam melakukan praktikum bekerjasama dengan baik dalam kelompoknya.

5) Interaksi penggunaan model pembelajaran NHT dan TPS dengan kemampuan matematik terhadap prestasi belajar

Siswa dengan kemampuan matematik tinggi jika diberi pembelajaran dengan model TPS mempunyai rerata prestasi yang lebih baik dibandingkan dengan jika diberi pembelajaran dengan model NHT berturut-turut 89,67 dan 85,67 . Demikian pula pada siswa dengan kemampuan awal rendah mempunyai rerata prestasi yang lebih baik jika diberi pembelajaran dengan model TPS dibandingkan dengan jika diberi pembelajaran dengan model NHT berturut-turut 79,00 dan 71,67. Sehingga dapat disimpulkan terdapat interaksi antara model pembelajaran TPS dan NHT dengan kemampuan matematik siswa. Kemampuan matematik adalah faktor internal yang berbeda untuk masingmasing siswa akan tetapi dengan model pembelajaran TPS siswa yang mempunyai kemampuan matematik tinggi akan lebih leluasa melakukan diskusi dan mengajarkan kepada pasangannya yang kurang pandai tentang suatu permasalahan yang berhubungan dengan penyelesaian secara matematik baik perhitungan matematik ataupun pemahaman tentang persamaan matematik. Hal ini sangat membantu siswa yang kemampuan matematiknya rendah sehingga pada akhirnya siswa tersebut mampu dan percaya diri untuk menyelesaikan persoalan yang membutuhkan kemampuan matematik. Sedangkan pada model NHT yang terdiri lebih banyak siswa terkadang waktu yang tersedia tidak cukup banyak untuk berdiskusi sehingga siswa yang berkemampuan matematik tinggi tidak efektif untuk mengajarkan kepada siswa yang kemampuan matematiknya rendah, sehingga pemahaman terhadap persoalan yang membutuhkan penyelesaian matematik juga kurang begitu baik.

Hasil uji prestasi afektif dan psikomotor menunjukkan tidak ada interaksi antara penggunaan model pembelajaran NHT dan TPS dengan kemampuan matematik tinggi dan rendah terhadap prestasi belajar afektif dan prestasi belajar psikomotor. Tidak adanya interaksi antara model pembelajaran dengan kemampuan matematik tinggi dan rendah terhadap prestasi afektif disebabkan karena perubahan perilaku afektif melalui proses yang membutuhkan waktu lebih lama, tidak serta merta dibandingkan aspek 
kognitif dan dukungan dari lingkungan (Diknas 2008). Selain itu pertanyaan-pertanyaan dalam angket untuk mengukur prestasi afektif tidak membutuhkan kemampuan matematik akan tetapi lebih kepada sikap dan perilaku siswa secara umum terhadap pembelajaran kelarutan dan Ksp. Selanjutnya tidak terdapat interaksi antara model pembelajaran dengan kemampuan matematik tinggi dan rendah terhadap prestasi psikomotor disebabkan lembar observasi untuk penilaian psikomotor melalui praktikum lebih ditekankan pada aspek keterampilan siswa misalnya dalam menggunakan alat dan melakukan pencampuran larutan yang tidak terlalu dipengaruhi oleh kemampuan matematik siswa dan siswa dalam melakukan praktikum bekerjasama dengan baik dalam kelompoknya.

6) Interaksi antara kemampuan awal dengan kemampuan matematik terhadap prestasi belajar.

Adams (2007) mengatakan bahwa ingatan jangka panjang yang tinggi memegang peranan dalam kemampuan matematik baik dalam proses perhitungan ataupun dalam penyimpanan informasi. Definisi-definisi kemampuan awal sesuai dengan teori-teori pengolahan informasi (information processing theory) yang pada intinya mengatakan bahwa kemampuan awal merupakan ingatan jangka panjang yang melalui tahap organisasi dan integrasi membangun hubungan antara pengetahuan yang relevan yang telah dikuasai sebelumnya dengan pengetahuan baru yang akan dipelajari. Sehingga dapat dikatakan bahwa terdapat interaksi antara kemampuan awal dan kemampuan matematik. Selanjutnya secara statistik kemampuan awal dan kemampuan matematik mempunyai prestasi kognitif yang lebih baik daripada siswa dengan kemampuan awal rendah dan kemampuan matematik rendah. Hal ini menunjukkan adanya interaksi antara kemampuan awal dan kemampuan matematik.

Hasil analisis untuk data afektif menunjukkan adanya interaksi antara kemampuan awal dan kemampuan matematik terhadap prestasi belajar afektif. Hal ini karena siswa dengan kemampuan awal tinggi dan kemampuan matematik tinggi memiliki kecenderungan pembentukan sikap, minat dan karakter yang lebih baik dibandingkan dengan kelompok lain. Siswa dengan kemampuan awal dan kemampuan matematik tinggi lebih mengerti tujuan atau arah pembelajaran karena mereka memiliki bekal kemampuan awal dan kemampuan matematik yang memadai.
Hasil tes untuk psikomotor menunjukkan tidak adanya interaksi antara kemampuan awal dan kemampuan matematik terhadap prestasi Penilaian psikomotor melalui praktikum lebih ditekankan pada aspek keterampilan siswa misalnya dalam menggunakan alat dan melakukan pencampuran larutan yang tidak terlalu dipengaruhi oleh kemampuan awal dan kemampuan matematik siswa dan siswa dalam melakukan praktikum bekerjasama dengan baik dalam kelompoknya sehingga nilai setiap kelompok tidak jauh berbeda.

7) Interaksi penggunaan model pembelajaran NHT dan TPS, kemampuan awal, dan matematik siswa terhadap prestasi belajar.

Hasil uji hipotesis kognitif menunjukkan ada interaksi antara model pembelajaran, kemampuan awal dan kemampuan matematik terhadap prestasi belajar kognitif siswa. Terdapatnya interaksi ini dapat dilihat dari hasil statistik menunjukkan bahwa model pembelajaran TPS lebih baik daripada model pembelajaran NHT. Siswa dengan kemampuan awal tinggi lebih baik daripada siswa dengan kemampuan awal rendah, siswa dengan kemampuan matematik tinggi lebih baik daripada siswa dengan kemampuan matematik rendah. Model pembelajaran, kemampuan awal dan kemampuan matematik secara simultan mempengaruhi prestasi belajar kognitif.

Hasil analisis prestasi afektif dan psikomotor menunjukkan tidak ada interaksi antara model pembelajaran, kemampuan awal dan kemampuan matematik terhadap prestasi belajar afektif dan prestasi belajar psikomotor. Hal ini disebabkan karena nilai afektif di setiap kelompok hampir sama, selain itu dalam penilaian afektif idealnya dilakukan model observasi dan laporan diri (angket). Model observasi berdasarkan pada asumsi bahwa karakteristik afektif dapat dilihat dari perilaku siswa. Sedangkan pada penelitian ini hanya menggunakan model angket sehingga mempengaruhi keakuratan data. Selanjutnya tidak adanya interaksi antara model pembelajaran, kemampuan awal dan kemampuan matematik terhadap prestasi belajar psikomotor disebabkan penilaian memiliki keterbatasan pada observasi ketika siswa melakukan praktikum sehingga hal ini juga mempengaruhi keakuratan data.

\section{Kesimpulan dan Rekomendasi}

Berdasarkan hasil uji hipotesis penelitian pada materi pokok kelarutan dan Ksp siswa kelas 
XI IPA SMA N 1 Sragen tahun pelajaran 2012/2013 maka dapat disimpulkan:

1. Terdapat pengaruh penggunaan model pembelajaran NHT dan TPS terhadap prestasi belajar kognitif, dengan model pembelajaran TPS lebih unggul dari NHT dilihat dari hasil analisis statistik. Sedangkan penggunaan kedua model pembelajaran ini tidak memberikan pengaruh terhadap prestasi afektif dan psikomotor siswa.

2. Terdapat pengaruh kemampuan awal terhadap prestasi belajar kognitif dan prestasi psikomotor, tetapi tidak terdapat pengaruh kemampuan awal terhadap prestasi afektif siswa.

3. Terdapat pengaruh kemampuan matematik terhadap prestasi belajar kognitif dan prestasi psikomotor, tetapi tidak terdapat pengaruh kemampuan matematik terhadap prestasi afektif siswa.

4. Terdapat interaksi antara model pembelajaran NHT dan TPS dengan kemampuan awal terhadap prestasi belajar kognitif siswa, tetapi tidak terdapat interaksi antara model pembelajaran NHT dan TPS dengan kemampuan awal terhadap prestasi afektif dan prestasi psikomotor siswa.

5. Terdapat interaksi antara model pembelajaran NHT dan TPS dengan kemampuan matematik terhadap prestasi belajar kognitif siswa, tetapi tidak terdapat interaksi antara model pembelajaran NHT dan TPS dengan kemampuan matematik terhadap prestasi afektif dan psikomotor siswa.

6. Terdapat interaksi antara kemampuan awal dan kemampuan matematik terhadap prestasi kognitif dan afektif siswa, tetapi tidak terdapat interaksi antara kemampuan awal dan kemampuan matematik terhadap prestasi psikomotor siswa.

7. Terdapat interaksi antara model pembelajaran NHT dan TPS, kemampuan awal dan kemampuan matematik terhadap prestasi kognitif siswa, tetapi tidak terdapat interaksi antara model pembelajaran NHT, TPS, kemampuan awal dan kemampuan matematik terhadap prestasi afektif dan psikomotor siswa.

Berdasarkan kesimpulan dalam penelitian ini, maka dapat diajukan rekomendasi sebagai berikut:

a. Model pembelajaran NHT dan TPS dapat diterapkan pada pembelajaran kimia materi kelarutan dan Ksp sehingga mempermudah siswa dalam mempelajari dan menguasai materi tersebut.

b. Kemampuan awal dan kemampuan matematik merupakan factor internal yang mempunyai pengaruh terhadap prestasi belajar, sehingga guru harus terus memperhatikan dan melatihnya agar dapat berpengaruh positif terhadap prestasi belajar siswa.

c. Prestasi belajar peserta didik dapat ditingkatkan dengan menggunakan model pembelajaran NHT dan TPS dengan memperhatikan kemampuan awal dan kemampuan matematik.

\section{Daftar Pustaka}

Adams, J.W. (2007). Individual differences in mathematical ablity: genetic, cognitive and behavioural factors. Journal of Research in Special Educational Needs. 7(2): 97-103.

Anita Lie. (2003). Cooperative Learning: Mempraktekkan Cooperative Learning di Ruang-ruang Kelas. Jakarta : Grasindo

Azlina, N.A. 2010. CETLs : Supporting Collaborative Activities Among Students and Teachers Through the Use of Think Pair Share Techniques, International Journal of Computer Science. 7(5) : 18 28.

Depdiknas. (2003). Standar Kompetensi Kurikulum 2004. Jakarta: Direktorat Pendidikan Menengah Umum.

(2008). Pengembangan Perangkat Penilaian Afektif. Jakarta: Direktorat Pendidikan Menengah Umum Depdiknas.

Dochy, F., Segers, M., \& Buehl, M.M. (1999). The Relation Between Assesment Practices an Outcomes of Studies: The Case of Research on Prior Knowledge. Review of Educational Research. 69 (2) : 145-186.

Kagan, S. \& Kagan, M. (2009). Cooperative Learning. San Clamente: Kagan Publishing. 
Kovas Y, Haworth C.M.A, Petrill S.A, Plomin R. (2007). Mathematical Ability of 10Year-Old Boys and Girls: Genetic and Environmental Etiology of Typical and Performance. Journal. Learn Disabil 40(6): 554-567.

Morgan, B.M. (2010). Cooperative Learning Effectiveness with Undergraduate Hispanic Students. National Forum Multicultural Issues Journal. 7(1):1-7.

Muijs, Daniel dan David Reynolds. (2008) Effective Teaching. Terjemahan: Helly $P$. Soetjipto. Yogyakarta : Pustaka Pelajar.

Nurhadi, B. Yasin, A.G. Senduk. (2004). Pembelajaran Kontekstual dan Penerapannya dalam KBK. Malang : Universitas Negeri Malang.

Peklaj, Cirila. (2000). Effects of Cooperative versus Individualistic Learning on Cognitive, Affective, Metacognitive and Sosial Processes in Students. European Journal of Psichology of Education. 14(3): 359-373.

Slavin, R.E. (2008). Cooperative Learning, Teori, Riset, dan Praktik. Bandung: Nusa Media.

Strangman, N and Hall, T. (2004). Background Knowledge. National Center on Accessing the General Curriculum. 13 (1) $: 1-10$ 